\title{
Antibiotic Resistance Pattern of Bacterial Pathogens Isolated from Cow Dung Used to Fertilize Nigerian Fish Ponds
}

\author{
Funso S. OMOJOWO', Folakemi P. OMOJASOLA2* \\ ${ }^{1}$ National Institute for Freshwater Fisheries Research (NIFFR), New Bussa, Niger State, Nigeria; omojowofs@yahoo.com \\ ${ }^{2}$ University of Ilorin, Faculty of Science, Department of Microbiology, P.M.B. 1515 Ilorin, \\ Kwara State, Nigeria; folakejasola@yahoo.co.uk ('corresponding author)
}

\begin{abstract}
This study was carried out to isolate and identify antibiotic resistant bacteria from cow dung used for pond fertilization. Cow dung from over 200 cows in NIFFR integrated farms, New-Bussa, Nigeria were collected. Six bacterial pathogens; Escherichia coli, E. coli O157:H7, Shigella dysentariae, Staphylococcus aureus, Salmonella typhi, and Aeromonas hydrophila were isolated. Antibiotic susceptibility testing by the disk diffusion method was conducted using ofloxacin, amoxicillin, tetracycline, ampicillin, erythromycin, gentamicin, nalidixic acid and chloramphenicol. All the isolated organisms were $100 \%$ sensitive to ofloxacin. The multiple resistance patterns revealed that $100 \%$ were resistant to tetracycline, ampicillin (85.6\%), amoxicillin (83.3\%), chloramphenicol (66\%), gentamicin (47.6\%), erythromycin (44.4\%) and nalidixic acid (18.3\%). The Public Health risks posed by the cow dung manure include proliferation of ponds with these organisms that are pathogenic to fish and man, contamination of the environment and the possible retention of these organisms in the table size fish.
\end{abstract}

Keywords: antibiotic resistance, manure, pathogenic organism, sensitivity

\section{Introduction}

Integrated fish farming is widely acceptable in aquaculture and is being practiced by the National Institute for Freshwater Fisheries Research (NIFFR), New-Bussa, Niger State, Nigeria. In this farming system, manure from livestock production is administered to fish ponds and the manure is directly consumed by fish. The release of nutrients supports the growth of fish with low input, with the fish receiving limited, if any, supplementary feed. The pond water becomes fertile upon the application of manure, resulting in more food organisms, thus a high fish production. However, organic manuring releases high concentrations of pathogenic microorganisms into the ponds constituting a high risk to fish and fish farmers. This is especially serious as an array of these bacteria has been reported to be resistant to antibiotics (Andreas et al., 2002; Olaitan et al., 2011). Antibiotics and other antibacterial drugs are the major weapons against disease-causing bacteria. They act in a number of ways to kill bacteria or suppress their activity. Antibiotics are regularly used in treating sick and diseased cow in the integrated units. Over time, however, bacteria can become resistant to antibiotics. Other practices contributing towards resistance include the addition of antibiotics to livestock feeds (Mathew et al., 2007).

In addition, unsavory practices in the pharmaceutical manufacturing industry such as production of counterfeit drugs can contribute towards the likelihood of creating antibiotic resistant strains (Larsson and Fick, 2009).
Emergence of bacteria resistant to antibiotics is common in areas where antibiotics are used, but occurrence of antibiotic resistance bacteria is also increasing in freshwater basin (Ash et al., 2002). The use of antibiotics as growth promoters in animal husbandry has been linked to certain antimicrobial resistance patterns among human bacterial pathogens (Bager et al., 1997; Wagener et al., 1999) suggesting that there is a possible flow of antimicrobial resistance genes between animal and human pathogens. Potential transfer of resistant bacteria and resistance genes from aquaculture environments to humans may occur through direct consumption of antimicrobial-resistant bacteria present in fish and associated products. Few studies on antibiotic resistance bacteria have been carried out on dumpsites, water sources, duck droppings in the environment and hospital environment (Ikpeme et al., 2011; Olaitan et al., 2011; Omololu-Aso et al., 2011) but fewer studies have been undertaken in dynamic integrated aquaculture environment where manure is used to fertilize fish ponds. Therefore, the objective of this study was to isolate and identify antibiotic resistant bacteria from cow dung used in fertilizing fish ponds. In addition, also examine the antibiotic susceptibility patterns of the isolated organisms.

\section{Materials and methods}

Sample collection

Samples of cow dung were randomly collected from NIFFR integrated farms in New-Bussa, Niger state, North 
16

central region of Nigeria. A total of 1000 samples were collected from over 200 cows raised in the integrated farm. The faecal samples were collected with sterile spatula into sterile peptone water and were analyzed within 1 hour of collection.

\section{Isolation and identification}

Isolation and identification of bacteria were investigated according to Bergey's Manual of Determinative Bacteriology (Holt et al., 1997). Pure cultures suggestive of $E$. coli were sub-cultured on Sorbitol MacConkey (SMAC) agar and incubated at $44.5^{\circ} \mathrm{C}$ for 24 hours to check for colonies that were colorless to pale (non- fermenting), flat and smooth, circular or serrated at the edge typical of $E$. coli $\mathrm{O} 157: \mathrm{H} 7$.

\section{Antibiotic Sensitivity Testing}

Antibiotic resistance of bacteria was determined by the single disc diffusion method with the use of MuellerHinton agar, according to the Bauer-Kirby method (Bauer et al., 1979). The following eight clinical antibiotics, with their concentrations given in parentheses were used in the antibiograms as recommended by the National Committee for Clinical Laboratory Standards (NCCLS, 2006): Tetracycline $(30 \mu \mathrm{g})$; Ofloxacin $(30 \mu \mathrm{g})$; Gentamicin $(20$ $\mu \mathrm{g})$; Erythromycin $(10 \mu \mathrm{g})$; Ampicillin $(10 \mu \mathrm{g})$; Chloramphenicol $(30 \mu \mathrm{g})$; Nalidixic acid $(30 \mu \mathrm{g})$ and Amoxicillin $(30 \mu \mathrm{g})$. After incubation, a clear circular zone of no growth in the immediate vicinity of a disk indicates susceptibility to that antimicrobial. Using reference tables the size of zones was related to the Minimum Inhibitory Concentration (MIC) and results recorded as whether the organism is susceptible $(\mathrm{S})$ or resistant $(\mathrm{R})$ to that antibiotic. Data was statistically analyzed using SPSS Version 12, level of significance $5 \%$.

\section{Results and discussion}

One hundred and thirty-two (132) bacteria were isolated from 1000 cow dung samples. These were: Escherichia coli: 66 (50\%); Aeromonas hydrophila 30 (22.7\%); Salmonella typhi 18 (13.6\%); Staphylococcus aureus 12 (9.1\%) and Shigella dysenteriae 6 (4.6\%) (Fig. 1). Twelve $12(18.2 \%)$ of the sixty-six (66) E. coli isolates from cow dung were non-fermenters typical of $E$. coli $\mathrm{O} 157: \mathrm{H} 7$ which represent $9.1 \%$ of total isolates from cow dung.

Overall, there was a $100 \%$ resistance to tetracycline by all the isolates, ampicillin (85.6\%), amoxicillin (83.3\%), gentamicin (47.6\%), chloramphenicol (66\%), erythromycin (44.4\%) and nalidixic acid (18.3\%). Multiple antibiotic drug resistance profiles have been reported in enteric bacteria from human and animal sources (Ikpeme et al., 2011; Olaitan et al., 2011; Troy et al., 2002). Resistance of a single bacterial isolate to more than one antimicrobial drug is commonly reported. There was no resistance to ofloxacin by all bacteria isolated. Salmonella typhi re-

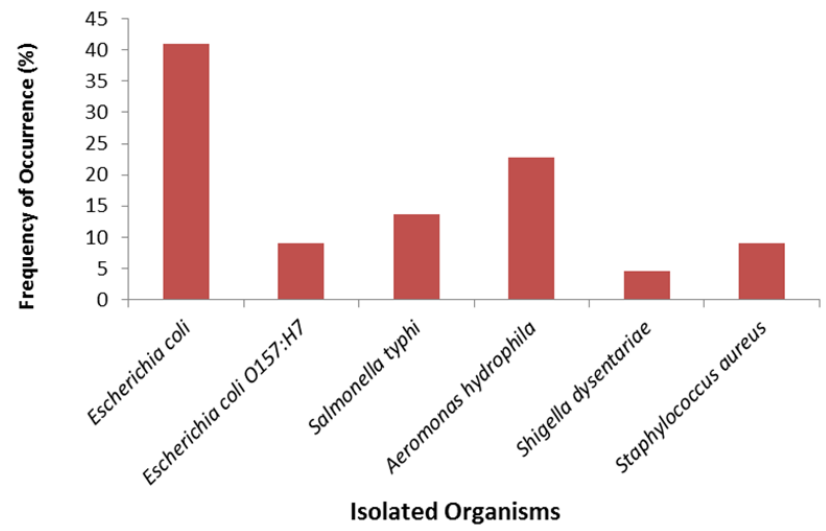

Fig. 1. Frequency of Occurrence of Isolated Organisms In Cow Dung used to fertilize Fish Ponds in New Bussa, Nigeria

corded $100 \%$ susceptibility to ofloxacin and nalidixic acid; $66.7 \%$ to erythromycin and $100 \%$ resistance to tetracycline; $66.7 \%$ resistance to gentamicin and ampicillin respectively (Fig. 2 ). These antibiotics are very common and are readily available as over-the-counter drugs to consumers in Nigeria (Omojasola and Omojasola, 2001) and may not be very useful for therapeutic purposes. The susceptibility pattern of $E$. coli (Fig. 3) showed the organism was susceptible to ofloxacin and nalidixic acid (100\%), chloramphenicol (77.8\%) and erythromycin (66.7\%). However, it had $100 \%$ resistance to amoxicillin, tetracycline and $66.7 \%$ resistance to ampicillin. E. coli O157:H7 recorded $100 \%$ susceptibility to ofloxacin, amoxicillin and nalidixic acid with $100 \%$ resistance to tetracycline, gentamicin, erythromycin and ampicillin respectively and $50 \%$ resistance to chloramphenicol (Fig. 4). Multiple antibiotic drug resistance in $E$. coli to ofloxacin and nalidixic acid has also been reported (Aibinu et al. 2004; Olaitan et al. 2011). This agrees with earlier reports that E. coli O157 isolates had high prevalence of resistance to tetracycline, sulfamethoxazole, cephalothin, and ampicillin (Carl et al., 2002; Zhao et al., 2001). Cattle is thought to be primary reservoirs of E. coli $\mathrm{O} 157$ and it is highly infectious as the infective dose for humans is reported to be $10 \mathrm{cfu}$, the lowest of the common foodborne pathogens. In addition, $E$. coli O157; $\mathrm{H} 7$ has high survival rates in as fecal counts as high as $4.2 \times 103 \mathrm{cfu} / \mathrm{mL}$ have been reported in 100 day old manure (Kress and Gifford, 1984).

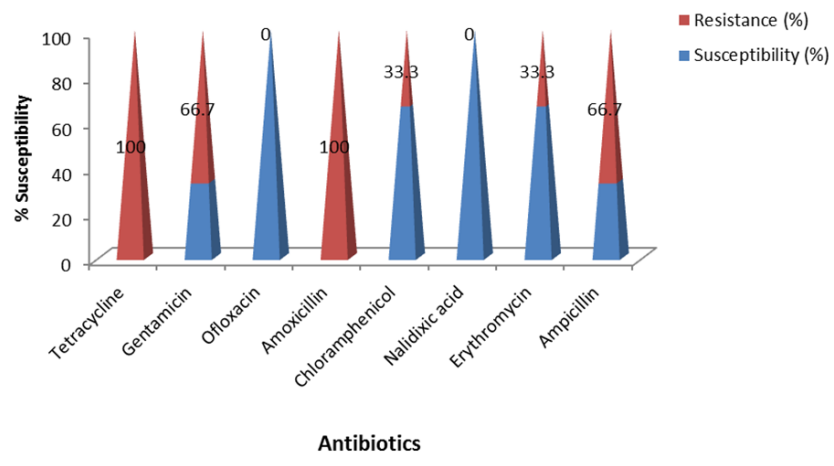

Fig. 2. Antibiogram of Salmonella typhi isolated from cow dung used to fertilize fish ponds in New Bussa Nigeria 
Tab. 1. Antibiotic Resistance profile of pathogenic bacteria isolates from Cow Dung used to fertilize fish ponds in New Bussa Nigeria

\begin{tabular}{ccccccccc}
\hline \multicolumn{7}{c}{ Antibiotic Susceptibility (Zone of inhibition in mm) } \\
\hline Isolates & TET & GEN & OFL & AMX & CHL & NAL & ERY & AMP \\
\hline Salmonella typhi & $\mathrm{R}(18)$ & $\mathrm{R}(16)$ & $\mathrm{S}(25)$ & $\mathrm{R}(13)$ & $\mathrm{S}(21)$ & $\mathrm{S}(26)$ & $\mathrm{S}(27)$ & $\mathrm{R}(11)$ \\
E. coli & $\mathrm{R}(17)$ & $\mathrm{R}(11)$ & $\mathrm{S}(28)$ & $\mathrm{R}(12)$ & $\mathrm{S}(23)$ & $\mathrm{S}(28)$ & $\mathrm{S}(29)$ & $\mathrm{R}(10)$ \\
E. coli $\mathrm{O} 157: \mathrm{H} 7$ & $\mathrm{R}(17)$ & $\mathrm{R}(10)$ & $\mathrm{S}(27)$ & $\mathrm{R}(13)$ & $\mathrm{S}(20)$ & $\mathrm{S}(26)$ & $\mathrm{R}(10)$ & $\mathrm{R}(11)$ \\
Shigella dysentariae & $\mathrm{R}(16)$ & $\mathrm{R}(11)$ & $\mathrm{S}(21)$ & $\mathrm{R}(10)$ & $\mathrm{R}(13)$ & $\mathrm{S}(20)$ & $\mathrm{S}(21)$ & $\mathrm{R}(10)$ \\
Aeromonas hydrophila & $\mathrm{R}(14)$ & $\mathrm{R}(10)$ & $\mathrm{S}(20)$ & $\mathrm{R}(9)$ & $\mathrm{R}(11)$ & $\mathrm{R}(16)$ & $\mathrm{R}(16)$ & $\mathrm{R}(8)$ \\
Staphylococcus aureus & $\mathrm{R}(17)$ & $\mathrm{S}(25)$ & $\mathrm{S}(26)$ & $\mathrm{R}(10)$ & $\mathrm{S}(23)$ & $\mathrm{S}(28)$ & $\mathrm{S}(24)$ & $\mathrm{R}(10)$ \\
\hline
\end{tabular}

$\mathrm{R}=$ Resistant, $\mathrm{S}=$ Susceptible, TET $=$ Tetracycline, GEN = Gentamicin, $\mathrm{OFL}=$ Ofloxacin; $\mathrm{AMX}=$ Amoxicillin; $\mathrm{CHL}=\mathrm{Chloramphenicol}$; NAL= Nalidixic acid; ERT= Erythromycin, AMP = Ampicillin
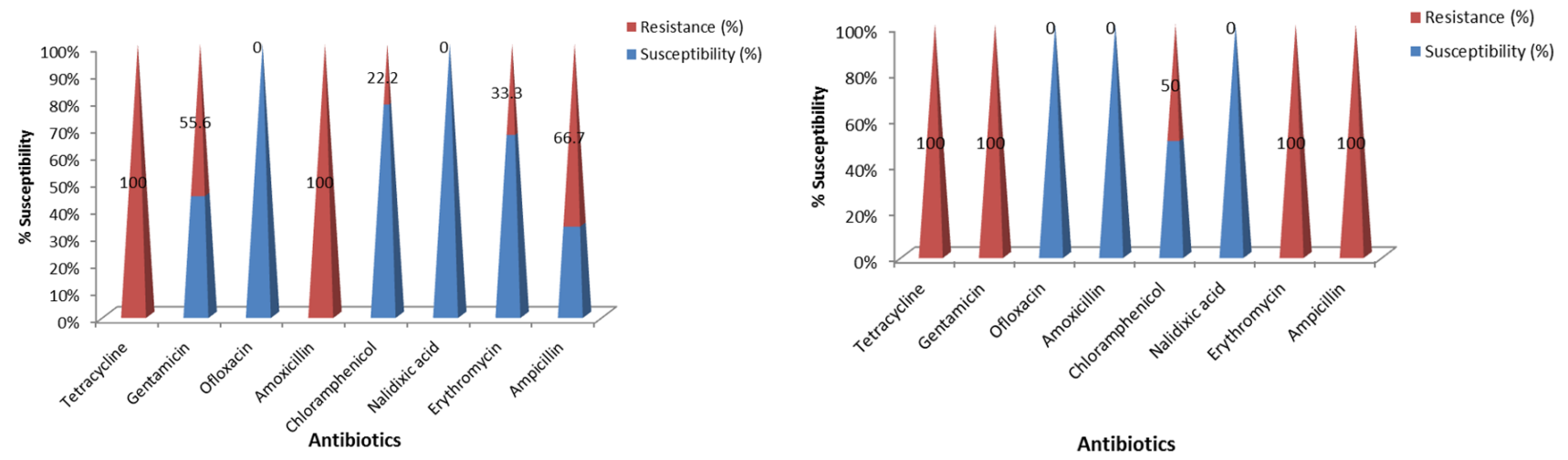

Fig. 3. Antibiogram of E. coli isolated from cow dung used to fertilize fish ponds in New Bussa Nigeria

Fig. 4. Antibiogram of E. coli O157:H7 isolated from cow dung used to fertilize fish ponds in New Bussa Nigeria

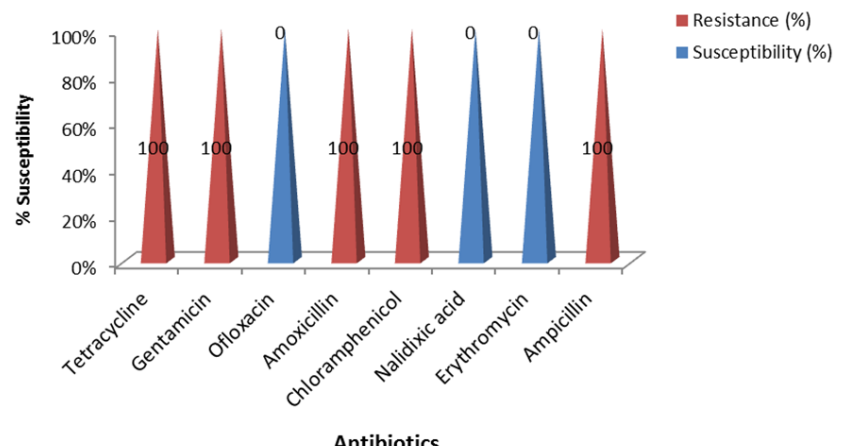

Fig. 5. Antibiogram of Shigella dysenteriae isolated from cow dung used to fertilize fish ponds in New Bussa Nigeria

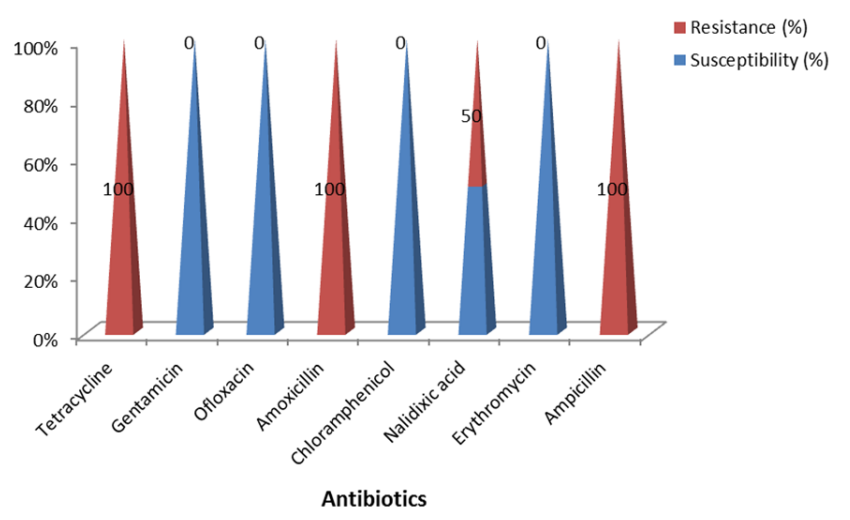

Fig. 7. Antibiogram of Staphylococcus aureus isolated from cow dung used to fertilize fish ponds in New Bussa Nigeria

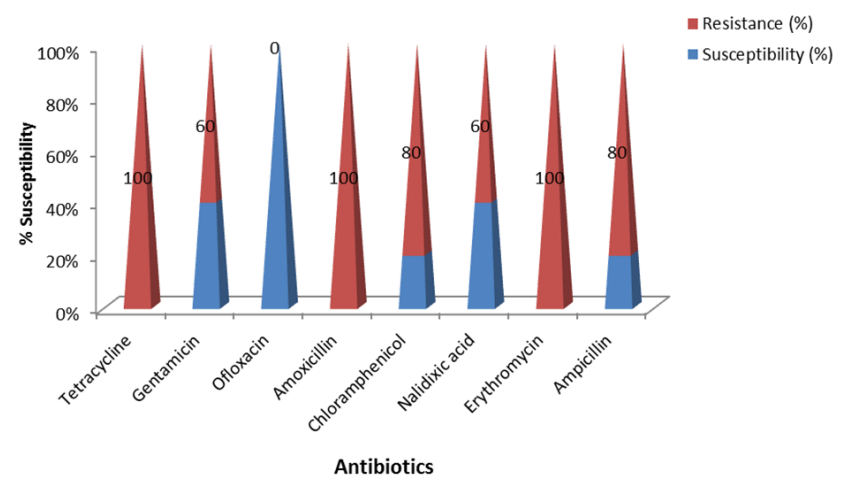

Fig. 6. Antibiogram of Aeromonas hydrophila isolated from cow dung used to fertilize fish ponds in New Bussa Nigeria

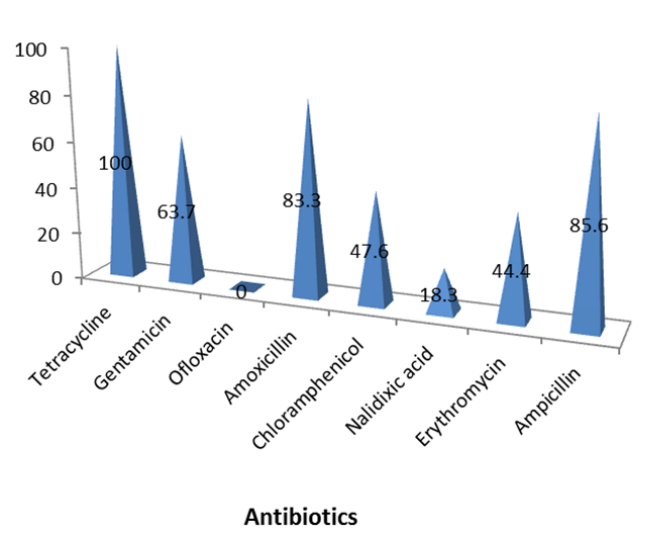

Fig. 8. Percentage Multiple Antibiotics Resistance 
18

Antibiogram results of the various isolates as presented in Tab. 1 show multidrug resistance by all isolates. Ofloxacin was the only antibiotic with no resistance by the isolated bacterial pathogens. However, the isolates had 100\% resistance to tetracycline, ampicillin (85.6\%), amoxicillin (83.3\%), chloramphenicol (66\%), gentamicin (47.6\%), erythromycin (44.4\%) and nalidixic acid (18.3\%).

There was $100 \%$ susceptibility of Shigella dysenteriae to ofloxacin, erythromycin and nalidixic acid respectively with $100 \%$ resistance to tetracycline, chloramphenicol and ampicillin respectively (Fig. 5) The high level of resistance of Shigella dysenteriae to tetracycline, chloramphenicol, ampicillin and gentamicin recorded in this study is similar to that of Ikpeme et al. (2011) who also reported resistance to tetracycline, chloramphenicol, ampicillin and gentamicin. Aeromonas hydrophila was 100\% susceptible to ofloxacin while it had $100 \%$ resistance to tetracycline, amoxicillin and erythromycin respectively. It also had 80\% resistance to chloramphenicol and ampicillin respectively while it had 60\% resistance to gentamicin and nalidixic acid respectively (Fig. 6). Moreover, Staphylococcus aureus was $100 \%$ susceptible to gentamicin, ofloxacin, chloramphenicol and erythromycin respectively while it was $50 \%$ susceptible to nalidixic. It had $100 \%$ resistance to tetracycline, amoxicillin ampicillin respectively (Fig. 7). The susceptibility recorded by $S$. aureus in this study for chloramphenicol and erythromycin were $100 \%$ respectively and is however slightly higher than the susceptibility reported by Omololu-Aso et al. (2011) for both chloramphenicol and erythromycin which were $95.12 \%$ and $73.98 \%$ respectively. Also, the susceptibility to gentamicin reported was $70.73 \%$ which was slightly lower compared to those reported in this study.

The patterns of resistance to the antimicrobial agents may be due to indiscriminate, widespread and lengthy use of tetracycline, chloramphenicol and gentamicin in treatment of cow infections. Tetracycline is a commonly used first-line antibiotic in the animal husbandry and is often used before the antimicrobial agent resistance of a pathogen has been determined (Prescott $e t$ al., 2000). The highest levels of susceptibility to all bacterial isolates found in this study were to ofloxacin and followed by nalidixic acid (Fig. 8) (Engberg et al., 2001; Sayah et al., 2004). The results suggest that livestock is a reservoir of resistant bacteria for environmental contamination, in agreement with the report of Sayah et al. (2004). Cow dung manure serves a potential carrier of pathogenic bacteria which are capable of transmitting zoonotic diseases to humans as a result of contact with the manure, when this untreated manure is used to fertilize fish ponds, it may lead to increase in bacterial infections in the fish and serves as a potential source of food borne infections for the fish consumers.

\section{Conclusions}

From this study, pathogenic bacteria were isolated from cow dung manure. The antibiotic sensitivity testing shows that all the organisms were $100 \%$ sensitive to ofloxacin. The isolates were most resistant to tetracycline, ampicillin and amoxicillin. Therefore potential role of manure fertilized ponds as source of antibiotic resistance in the environment should further be studied. It is recommended that manure intended for pond fertilization should be treated before use. In addition, the implication of this high level of antibiotic resistance on the choice of antibiotics in relation to zoonotic infections should be noted and efforts should be made to stop indiscriminate use of antibiotics.

\section{Acknowledgements}

This data is part of an ongoing Ph.D. study, the author is grateful to the Executive Director of NIFFR, New-Bussa, Niger-state, Nigeria for sponsorship.

\section{References}

Aibinu I, Adenipekun E, Odugbemi T (2004). Emergence of quinolone resistance amongst Escherichia coli. Nigerian J on Health. Biomed Sci 3(2):73-78.

Andreas P, Jens SA, Tawatchai K, Temdoung S, Anders D (2002). Impact of integrated fish farming on antimicrobial resistance in a pond environment. Appl Environ Microbiol 68(12):6036.

Ash RJ, Mauck B, Morgan M (2002). Antibiotic resistance of Gram-negative bacteria in rivers, Unites States. Emerg Infec Dis 8:713-716.

Bager F, Madsen M, Christensen J, Aarestrup FM (1997). Avoparcin used as a growth promoter is associated with the occurrence of vancomycin resistant Enterococcus faecium in Danish poultry and pig farms. Prev Vet Med 31:95-112.

Bauer AW, Kirby WM, Sherris JC (1979). Antibiotics susceptibility testing by a standardized single disk method. American J Clinical Pathogen 45:493-496.

Carl MS, Cuiwei Z, Chitrita D, Jocelyn T, Shaohua Z, David GW, David DW, Patrick FMcD, Robert DW, Jianghong M (2002). Antimicrobial resistance of Escherichia coli O157 isolated from humans, cattle, swine, and food. Appl Environ Microbiol 68(2):576-581

Engberg J, Aarestrup FM, Taylor DE, Gerner-Smidt P, Nachamkin I (2001). Quinolone and macrolide resistance in Campylobacter jejuni and E. coli: resistance mechanisms and trends in human isolates. Emerg Infect Dis 7:24-34.

Holt GH,. Kreig NR, Sneath PHA, Staley JT, Williams ST (1997). Bergey's manual of determinative bacteriology. $9^{\text {th }}$ Ed., Williams and Wilkins, New York.

Ikpeme E, Nfongeh J, Enyi-Idoh K, Eja ME, Etim L (2011). Antibiotic susceptibility profiles of enteric bacterial isolates from dumpsite utisols and water sources in a rural community in cross river state, southern Nigeria. Nature and Sci 9(5):46-50.

Kress M, Gifford GK (1984). Fecal coliform release from cattle fecal deposits. Water Resour Bull 20(1):61-66.

Larson DG, Fick J (2009). Transparency throughout the production chain-a way to reduce pollution from the manufactur- 
ing of pharmaceuticals. Regul Toxicol Pharmacol 53:161.

Matthew AG, Cissell R, Liamthong S (2007). Antibiotic resistance in bacteria associated with food animals: a United States perspective of livestock production. Foodborne Path Dis $4(2): 115-33$.

National Committee for Clinical Laboratory Standards (NCCLS) (2006). Methods for dilution antimicrobial susceptibility test for bacterial that grow aerobically, $4^{\text {th }}$ Edition.

Olaitan JO, Shittu OB, Akinliba AA (2011). Antibiotic resistance of enteric bacteria isolated from duck droppings. J Appl Biosci 45:3008-3018.

Omojasola PF, Omojasola TP (2001). Urinary tract infection among adult subjects in Ilorin Metropolis. NISEB J 1(3):205-209

Omololu-Aso J, Kolawole DO, Omololu-Aso OO, Ajisebutu SO (2011). Antibiotics sensitivity pattern of staphylococcus aureus from fomites in the Obafemi Awolowo University Teaching Hospital Complex (OAUTHC) Nigeria. Internat J Med and Medical Sci 3(2):32-36.

Prescott JF, Baggot JD, Walker RD (Ed.) (2000). Antimicrobial therapy in veterinary epidemiology, $3^{\text {rd }}$ ed. Iowa State University Press, Ames.
Sayah RS, John BK, Yvette J, Rose AM (2005). Patterns of antimicrobial resistance observed in Escherichia coli isolates obtained from domestic-and wild-animal fecal samples, human septage, and surface water. Appl Environ Microbiol 71:1394-1404.

Troy MS, Rose JB, Jenkins TM, Farrah SR, Lukasik J (2002). Microbial source racking: current methodology and future directions. Appl Environ Microbiol 68:5796-5803.

Wegener HC, Aarestrup FM, Jensen LB, Hammerum AM, Bager F (1999). Use of antimicrobial growth promoters in food animals and Enterococcus faecium resistance to therapeutic antimicrobial drugs in Europe. Emerg Infect Dis 5:329335.

Zhao S, White DG, Ge B, Ayers S, Friedman S, English L, Wagner D, Gaines S, Meng J (2001). Identification and characterization of integron-mediated antibiotic resistance among Shiga toxin-producing Escherichia coli isolates. Appl Environ Microbiol 67:1558-1564. 